\title{
ВЛИЯНИЕ ПАНДЕМИИ НА МОРСКИЕ ГРУЗОПЕРЕВОЗКИ
}

\author{
Казаков Станислав Александрович, \\ студент ФГАОУ ВО «Северо-Кавказский \\ федеральный университет»
}

Аннотация. В статье анализируются основные проявления воздействия пандемии COVID-19 на систему морских грузоперевозок. Рассматриваются основные причины, повлиявшие на изменения в системе морских грузоперевозок. Анализ влияние Китая на сложившуюся ситуацию в сфере морской торговли.

Annotation. The article analyzes the main manifestations of the impact of the COVID-19 pandemic on the shipping system. The main reasons that influenced the changes in sea freight are considered. Analysis of China's influence on the current situation in the field of maritime trade.

Ключевые слова: COVID-19, Морские торговые пути, морские грузоперевозки, Китай, контейнеры.

Keywords: COVID-19, Sea trade routes, sea freight, China, containers.

Морские грузоперевозки являются основой международной торговли. $90 \%$ всех товаров поставляется благодаря морским торговым путям, поскольку данный способ экспорта товаров - самый дешевый из всех существующих в мире. Морские торговые пути стали, своего рода, кровеносной системой мировой торговли изменение статуса которых влияет на все товары. В связи с этим, значительный интерес вызывает влияние пандемии COVID-19 на сложившуюся систему морских грузоперевозок.

В основе всех грузоперевозок лежат 3 константы: перевозимый объект, начальная и конечная точки, маршрут. Для сухопутных и воздушный грузоперевозок наибольший приоритет отдаётся тому, куда нужно произвести доставку и каким маршрутом это будет наиболее эффективно. Для морских грузоперевозок ситуация меняется. В зависимости от того в какую часть света необходимо доставить груз, будет выбран один из уже созданных маршрутов. Груз в виде контейнеров загружают на борт, которые будут доставлены и разгружены в точке назначения. В дальнейшем на борт судна будут загружена партия контейнеров для доставки в точку, из которой судно стартовало и будет разгружено там. Таким образом формируется сбалансированная система грузоперевозок в основе которой лежит обмен контейнеров между портами. Однако, возникшая пандемии COVID-19 сильно повлияла на данный процесс.

В начале 2020 года в Китае возникла вспышка вирус COVID-19. Китайские власти решили действовать оперативно, в результате чего город Ухань был введён жесткий карантин, началось быстрое строительство новых больниц и дезинфекция городов. Благодаря данным действиям, Китай смог уже к маю 2020 года смог прийти в норму. Однако, начиная с мая 2020 года, другие страны начали вводить у себя карантинные меры. Данные действия привели к тому, что было резко изменено потребление покупателей. Расходы на активности вне дома упали, параллельно с этим вырос спрос на средства индивидуальной защиты от вирусов и товаров домашнего пользования. Ключевой момент в том, что большинство таких товаров производится в Китае. Таким образом, Китай начал наращивать экспорт товаров в другие страны по морю. Однако по причине ограничительных мер в странах покупателях, контейнеры, используемые для доставки товаров не возвращаются в Китай. Из-за введенных ограничений страны не работают на экспорт товаров собственного производства, параллельно с этим, работа портов была также замедлена по причине введенных ограничений. В совокупности, это привело к тому, что контейнеры начали складироваться в портах Европы и Америки.

Данная тенденция привела к тому, что цена за транспортировку одного контейнера из Китая в июле превысила 2000 долларов, а на данный момент превышает 5000 долларов. К тому же, из-за введенных ограничений, в портах находится меньше рабочей силы, что в свою очередь влияет на скорость загрузки судов для обратного маршрута, не считая того что объема товара на продажу не достаточно для полного заполнения судна. Исходя из этого, перевозчики фокусируются на поставке груза из Азии, чему способствует поставки товаров в объемах, превышающих до пандемии. Однако это не значит, что данная ситуация выгодна для Китая. В целях мотивации перевозчиков, Китай начал доплачивать за возврат пустых контейнеров, но из-за этого, интересы перевозчиков сместились с поставки товаров на поставку готовых, пустых контейнеров.

Таким образом, можно сделать не утешительный вывод о том, что пандемия COVID-19 сказалась на международных морских перевозках крайне неприятным образом. Рост дефицита контейнеров в Азии приведёт к росту цены на их производство. Производители поднимают цены на новые ящики, при этом, не спеша наращивать производство. Беря в расчет то, что $85 \%$ в доле производства контейнеров занимает Китай, это вызывает подозрения у США в намеренном сохранении дефицита в целях получения большей прибыли. Созданные таким образом условия экспорта не позволяют в должной мере сбалансировать систему морских грузоперевозок, в результате чего вероятность роста цен на бытовые вещи становится крайне высокой, что в свою очередь может вызвать их дефицит на рынке. Однако наибольшее опасение вызывает тот факт, что подлинно не известно, когда экономика обретёт баланс и на сколько долгосрочными окажутся последствия. 
1) BE FORWARD Official Container Shortage Explained 2021 [видео объяснение]// YouTube 1 февраля 2021 г (https://www.youtube.com/watch?v=1oPhpMGqfgE\&ab_channel=BEFORWARDOfficial) Просмотрено: 01.06.2021.

2) Port of Los Angeles Cargo Surge Breaks March, First Quarter Records at the Port of Los Angeles [видео отчет]// YouTube 1 февраля 2021 Г (https://www.youtube.com/watch?v=vhluRwWmPrY\&ab_channel=PortofLosAngeles) Просмотрено: 01.06.2021.

3) World Container Index - 27 May//Drewry.co.uk [Электронный pecypc]. URL: https://www.drewry.co.uk/supplychain-advisors/supply-chain-expertise/world-container-index-assessed-by-drewry (дата обращения 01.06.2021). 